\title{
The impact of early precommercial thinning of dense jack pine [Pinus banksiana Lamb.] stands on the mortality of thinned stems
}

\author{
by T.B. Splawinski ${ }^{1}$, S. Gauthier², Y. Bergeron ${ }^{3}$ and D.F. Greene ${ }^{4}$
}

\begin{abstract}
Precommercial thinning of jack pine (Pinus banksiana) stands is a common silvicultural method to control stand density and growth in managed boreal forest stands. If employed too early, vigorous conifer re-growth can reduce the radial growth and potential yield of residual trees, thus requiring additional costly thinning treatments and extended rotation period. We examine thinned jack pine re-growth proportion as a function of remaining branch whorls on the stump of cut stems, and of thinning height following fire and salvage. Four salvaged and precommercially thinned stands in two forest fires that occurred in 1995 in the Abitibi-Temiscamingue region of Quebec were sampled. Significant relationships were identified between the number of branch whorls remaining on individual stems following precommercial thinning and the mortality proportion, and between the number of branch whorls remaining on individual stems following precommercial thinning and mean stump height. We suggest that precommercial thinning in dense jack pine stands be applied between 7 and 10 years following establishment at between $10 \mathrm{~cm}$ and $13 \mathrm{~cm}$ stump height. In addition, we identify various indicators that foresters can use on-site to better plan thinning operations.
\end{abstract}

Keywords: precommercial thinning, jack pine, stump mortality, branch whorls, thinning height, growth, rotation age, fire, salvage

\section{RÉSUMÉ}

Léclaircie précommerciale des peuplements de pin gris (Pinus banksiana) est une application sylvicole courante pour contrôler la densité et la croissance des peuplements forestiers boréaux sous aménagement. Si elle est appliquée trop tôt, la reprise vigoureuse de la croissance des conifères peut réduire la croissance radiale et le rendement potentiel des arbres résiduels, ce qui entraîne des coûts additionnels déclaircie et rallonge la période de révolution. Nous avons étudié la proportion de la reprise de croissance chez le pin gris après éclaircie en tant que fonction des verticilles retrouvés sur la souche des tiges coupées et de la hauteur de léclaircie à la suite d'un feu et d'une coupe de récupération. Quatre peuplements ayant fait lobjet d'une coupe de récupération et d'une éclaircie précommerciale sur le site de deux feux de forêt survenus en 1995 dans la région de l'AbitibiTémiscamingue au Québec ont été échantillonnés. Des relations significatives ont été relevées entre le nombre de verticilles présents sur chacune des tiges après léclaircie précommerciale et la proportion de la mortalité, ainsi quentre le nombre de verticilles présents sur chaque tige après léclaircie commerciale et la hauteur de souche moyenne. Nous suggérons que léclaircie précommerciale dans le cas de peuplements denses de pin gris soit réalisée entre 7 et 10 ans après létablissement du peuplement et à hauteur de $10 \mathrm{~cm}$ à $13 \mathrm{~cm}$ au-dessus de la souche. De plus, nous identifions les différents indicateurs que les forestiers peuvent utiliser sur le site pour mieux planifier les opérations déclaircie.

Mots clés : éclaircie précommerciale, pin gris, mortalité de la souche, verticilles, hauteur déclaircie, croissance, révolution, feu, récupération

\footnotetext{
${ }^{1}$ Institute of Environmental Science, Université du Québec à Montréal, 141, avenue du Président-Kennedy, Montreal (Quebec) H2X 1Y4. E-mail: tsplawinski@gmail.com

${ }^{2}$ Natural Resources Canada, Canadian Forest Service, Laurentian Forestry Centre, 1055 rue du PEPS, P.O. Box 10380, Stn. Sainte Foy, Québec, G1V 4C7.

${ }^{3}$ Centre détude sur la forêt and Chaire industrielle en aménagement forestier durable, Université du Québec à Montréal, CP 8888 Succursale A, Montréal, Québec H3C 3P8.

${ }^{4}$ Department of Geography, Planning and Environment, Concordia University, 1455 de Maisonneuve Blvd. West, Montréal, Québec H3G 1M8.
} 


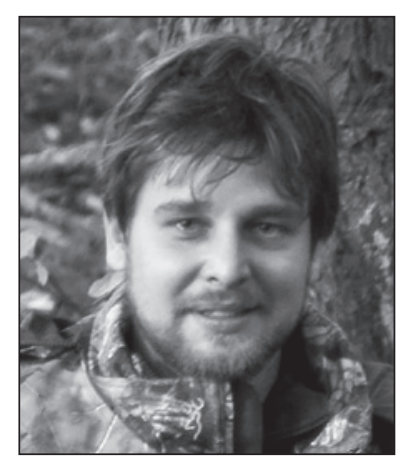

T.B. Splawinski

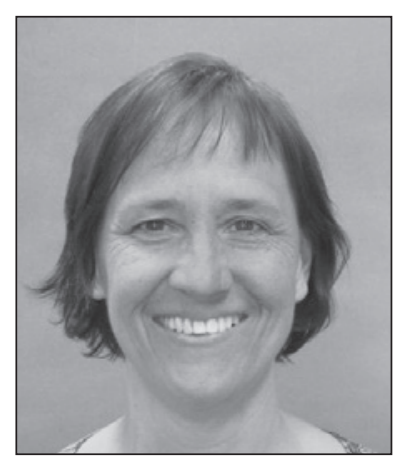

S. Gauthier

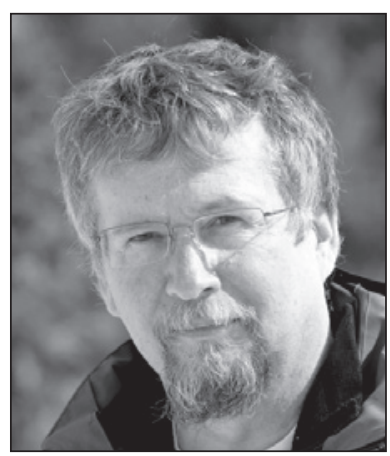

Y. Bergeron

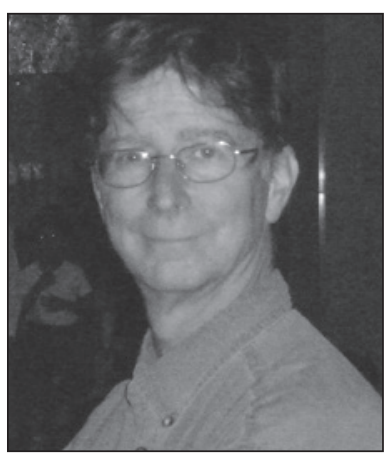

D.F. Greene

\section{Introduction}

Natural regeneration densities of jack pine, a serotinous, shade intolerant conifer (Fowells 1965, Rudolph and Laidly 1990, Sims et al. 1990, Lamont et al. 1991, Gauthier et al. 1993, Enright et al. 1998, Greene et al. 1999, Claveau et al. 2002), can be high (Bella 1974, De Groot et al 2004), reaching up to 200000 stems/ha following fire (Splawinski et al. Unpublished). For harvested areas, reforestation methods such as spot seeding, aerial broadcast seeding and the redistribution of cone-bearing slash through scarification can also result in relatively high stem densities (Van Damme and McKee 1990). While these over-stocked stands often require precommercial thinning treatments to reduce density and improve residual growth and volume (Vassov and Baker 1988), success is highly dependent on treatment timing (Riley 1973). Precommercial thinning of jack pine (Pinus banksiana Lamb.) stands is a common silvicultural method to control stand density and growth in managed boreal forest stands in Canada (Vassov and Baker 1988), especially in dense, xeric post-fire stands (Riley 1973, Smith 1984).

Stem density will determine the timing of the onset of the self-pruning phase (Vassov and Baker 1988). The higher the stem density, the faster the self-pruning of lower branches will

begin in order to minimize energy loss. Precommercial thinning is typically applied at the juvenile stage, 6 to 12 years after the stand origin, when intense competition for space, light and nutrients begins to reduce the radial growth of commercially important conifers, thereby reducing stand volume and extending rotation period (Vassov and Baker 1988). Its use must be carefully timed; if employed too early, vigorous hardwood and conifer re-growth can reduce the radial growth and potential yield of residual trees, thus requiring additional costly thinning treatments and extending rotation period; If delayed too long, treatment costs increase and radial growth decreases (Riley 1973).

In the event of top injury, and depending on the level of damage, vertical growth from the remaining living branches can occur. These then become the new leaders, allowing the tree to re-grow (Fig. 1) (Riley 1973). In a rough sense, the success of thinning is inversely proportional to the density of re-grown stems.

Density, stocking, spacing, and diameter and height growth response of jack pine following precommercial and commercial thinning has been extensively studied (Skilling 1957; Cayford 1961, 1964; Buckman 1964; Steneker 1969; Riley 1973; Bella 1974, Bella and de Franceschi 1974; Benzie 1983;

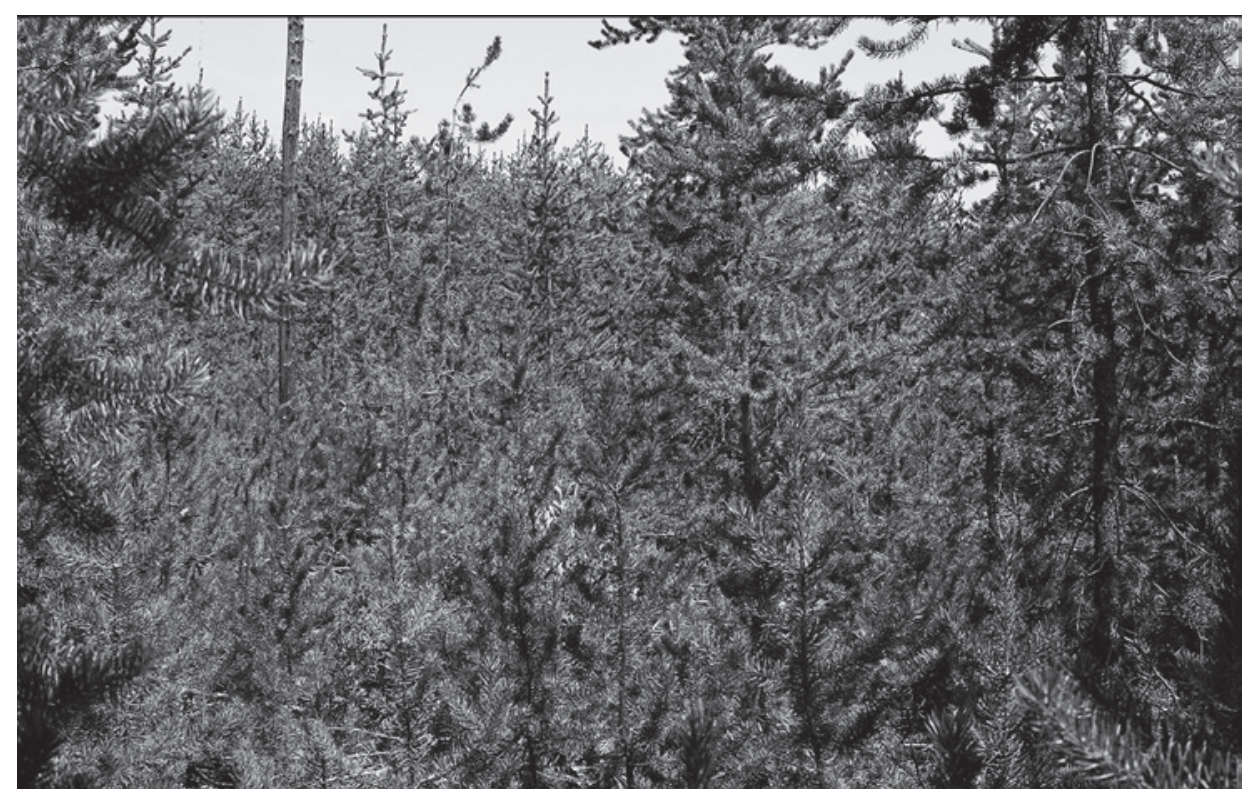

Fig. 1. Observed re-growth of thinned stems in site 1 from the current study. Note the high density and height of re-grown stems, as well as the lack of crown closure.
Smith 1984; Goble and Bowling 1993; Morris et al. 1994; Bulley et al. 1997; OMNR 1998), and the problematic nature of whorl re-growth has been briefly outlined by $\mathrm{Ri}$ ley (1973). However, we know of no studies that examine thinned jack pine mortality percentage as a function of either the remaining number of branch whorls on the stump of cut stems or thinning height. Specific industrial guidelines for jack pine thinning height based on scientific studies are also lacking.

Riley (1973) determined that, while precommercial thinning was most economical in younger jack pine stands, timing was important. He observed 
that surviving whorls growing close to the ground led to dense re-growth of thinned jack pine stems in the two years following thinning. In the same study area, Smith (1984) examined jack pine stocking, density and height and diameter response to precommercial thinning, and found that thinning as close to the ground as possible resulting in minimal re-growth.

A study examining live limb survival and development on stumps following precommercial thinning in the closely-related lodgepole pine (Pinus contorta Dougl. ex Loud. var. latifolia Engelm.) and coastal western hemlock (Tsuga heterophylla [Raf.] Sarg.) found variable stump survival depending on treatment (Forrester and von der Gonna 1990). Stumps thinned closest to the ground, with the fewest remaining live limbs, exhibited the greatest mortality. Gay (1987) also reported survival of stumps with live limbs following treatment in a lodgepole pine stand.

The objectives of this study on the precommercial thinning of jack pine are to (1) examine the relationship between thinning height and the number of remaining branch whorls; (2) examine the relationship between the number of remaining branch whorls and the percent mortality of these thinned stems; (3) determine the thinning height that results in the greatest mortality of thinned stems; and finally (4) propose guidelines to improve thinning success based on thinning height and timing of operations in dense stands, thereby increasing growth and yield.

We propose the following hypotheses: (1) thinning treatments that leave no living branch whorls on the remaining stump will result in $100 \%$ stem mortality; and (2) the mortality of thinned stems will be inversely proportional to the number of remaining post-thinning whorls.

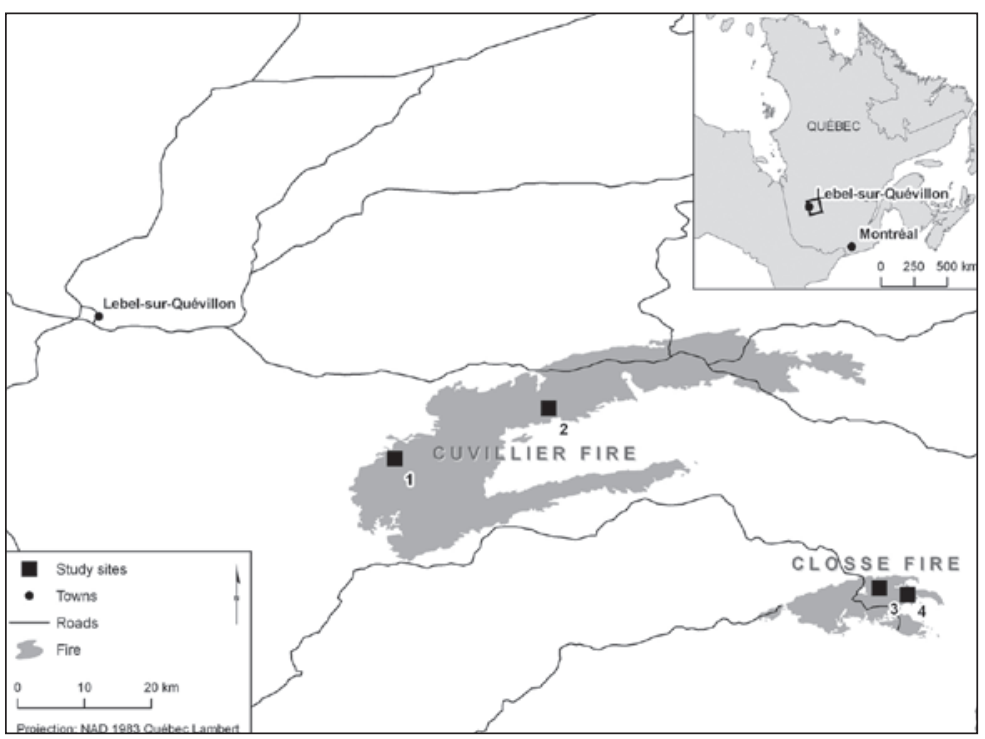

Fig. 2. Map of study area and site locations.

\section{Methodology}

\section{Study area}

We sampled four salvaged and precommercially thinned (by brush-saw) stands in two forest fires that occurred in 1995 in the Abitibi-Temiscamingue region of Quebec (Fig. 2). All four stands were dominated by jack pine, found on a surficial deposit of sand of glaciolacustrine origin, with no evidence of crown closure at the time of data collection (Fig. 1).

Two sites (site 1 and 2) were established in the Cuvillier fire, which is located in northwestern Quebec $40 \mathrm{~km}$ southeast of the town of Lebel-sur-Quevillon $\left(48^{\circ} 49.513^{\prime} \mathrm{N}\right.$, $\left.76^{\circ} 37.224^{\prime} \mathrm{W}\right)$. Ignited accidentally by man on August 16 1995, it burned 47709 ha of forest before it was extinguished by rain on October 20.

Two sites (site 3 and 4) were established in the Closse fire, which is located in northwestern Quebec $100 \mathrm{~km}$ southeast of the town of Lebel-sur-Quevillon $\left(48^{\circ} 41.242^{\prime} \mathrm{N}\right.$, $\left.75^{\circ} 58.793^{\prime} \mathrm{W}\right)$. Ignited accidentally by man on August 20 1995, it burned 6925 ha of forest before it was extinguished by rain on October 20.

Sites were identified in the summer of 2010 and data collection occurred over the summer of 2011 and 2012. Site details can be found in Table 1 .

Ten $4-\mathrm{m}^{2}$ plots spaced $10 \mathrm{~m}$ apart were established in each site to determine both the pre- and post-thinning density of jack pine. In addition, the following data were recorded for each individual thinned stem: stump height (rounded to the nearest centimeter); the number of branch whorls (dead or alive) remaining on the thinned stump; and the living status of the stump (dead or alive). Based on our field observation we suggest that all stumps remaining after thinning were still present at the time of data collection. The stumps that were present showed low levels of decomposition; indeed, the great majority still had bark present, with clearly visible branch whorls.

\section{Numerical and statistical analysis}

ANOVA was used to compare the mean thinning height by site, the mean thinning height by site which would leave zero branch whorls on the stem, and the mean thinning height by site which would leave no more than one (data lumped) branch whorls on the stem. Levels of significant factors were compared using Tukey's HSD post-hoc method.

To study the effect of thinning height on the number of remaining branch whorls while controlling for sites, we used an analysis of covariance. we used an analysis of covariance; model effects

Table 1. Site details.

\begin{tabular}{lcccccc}
\hline Site & Drainage & $\begin{array}{c}\text { Organic layer } \\
\text { depth }(\mathbf{c m})\end{array}$ & $\begin{array}{c}\text { Precommercial } \\
\text { thinning year }\end{array}$ & $\begin{array}{c}\text { Thinned jack } \\
\text { pine (stems/ha) }\end{array}$ & $\begin{array}{c}\text { Sample size of } \\
\text { thinned stems }\end{array}$ & $\begin{array}{c}\text { Mortality of } \\
\text { thinned stems (\%) }\end{array}$ \\
\hline 1 (highly xeric) & excessive & 2 & 2004 & 54250 & 217 & 45.62 \\
2 (mesic) & moderate & 12 & 2005 & 74000 & 296 & 71.62 \\
3 (xeric) & well drained & 5 & 2002 & 93500 & 373 & 76.36 \\
4 (xeric) & well drained & 3 & 2002 & 60250 & 241 & 76 \\
\hline
\end{tabular}


included the 4 sites stump heights (continuous), and the interaction between the two. Sites were compared using Tukey's HSD post-hoc method.

To study the effect of remaining number of branch whorls on the mortality frequency (all sites lumped) we used $\mathrm{Chi}^{2}$. Branch whorl numbers were merged into classes when frequencies were too low to meet the requirement of an unbiased test.

Variables were log-transformed when ANOVA assumptions of normality and homoscedasticity were not met. A $\alpha$ value of 0.05 was used for all statistical analyses.

\section{Results}

Site data on stems thinned, sample size, and mortality \% can be found in Table 1.

\section{Mean cut height by site}

ANOVA analysis indicates that the sites were thinned at significantly different mean cut heights (Prob. $>\mathrm{F}<0.0001$ ) (Fig. 3 ). Cut heights were significantly greater in sites 2 and 4 than in site 3, which in turn were greater than in site 1 (Tukey HSD). Variables were log-transformed as ANOVA assumptions of normality and homoscedasticity were not met.

\section{Number of branch whorls versus stump height}

As stump height increased so did the number of remaining branch whorls. An analysis of covariance indicates significant differences in the number of observed branch whorls between sites (Prob. $>\mathrm{F}<0.0001$ ), and a significant relationship between stump height and number of remaining branch whorls (Prob. $>$ $\mathrm{F}<0.0001$ ), but not in slope (Prob. $>\mathrm{F}=0.5408)$ (Fig. 4).

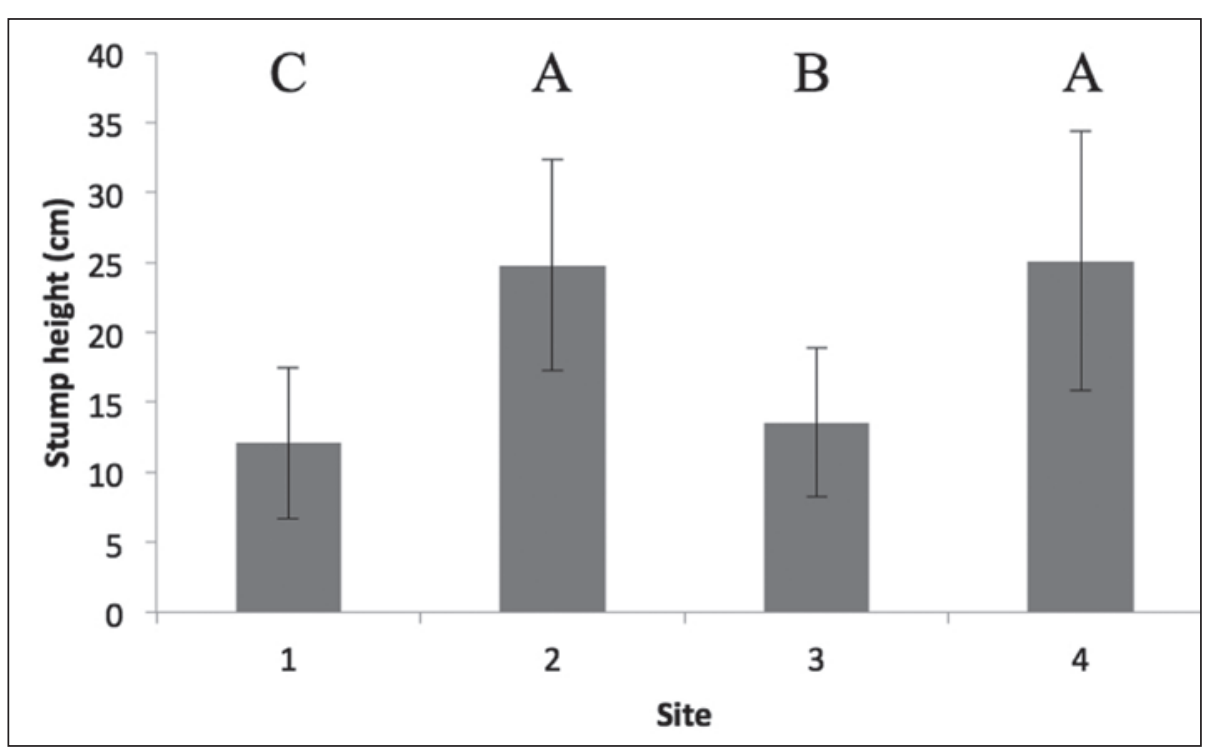

Fig. 3. Mean cut height $(\mathrm{cm})$ by site. ANOVA Prob. $>\mathrm{F}<0.0001$. Error bars represent standard deviation.

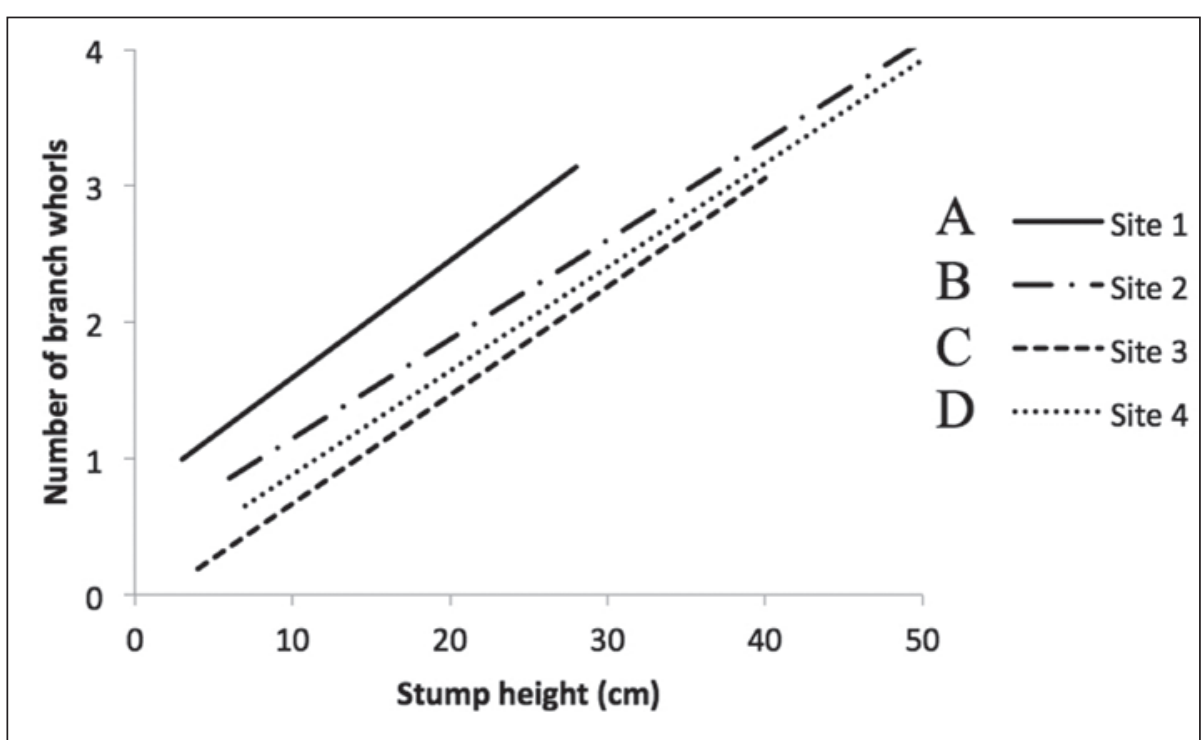

Fig. 4. Analysis of covariance studying the effects of site and stump height on the number of remaining branch whorls. Letters illustrate significant differences in number of branch whorls between sites.

\section{Mortality frequency and the number of remaining branch whorls}

We observed that if thinning removed all branch whorls from the thinned stem, $100 \%$ stem mortality occurred. Fig. 5 illustrates the results of $\mathrm{Chi}^{2}$ for lumped data. The relationship between mortality frequency and the number of remaining branch whorls was significant without significant differences among sites. Mortality was similar when zero or one whorl was left, and significantly higher than that of stumps with more than two whorls.

\section{Thinning height}

ANOVA analysis indicates that a significant difference exists in the mean cut height yielding zero branch whorls between sites (Prob. $>\mathrm{F}=0.007$ ). The mean thinning height observed in site 1 is significantly inferior to the other sites (Tukey HSD). Variables were log-transformed as ANOVA assumptions of normality and homoscedasticity were not met. Site 1 has a mean thinning height of $5 \mathrm{~cm}(95 \% \mathrm{CI}$ of $2 \mathrm{~cm}$ and $9 \mathrm{~cm}$. while the mean for sites 2,3 , and 4 lumped is $11 \mathrm{~cm}$ ( $95 \%$ confidence interval of $10 \mathrm{~cm}$ and $11 \mathrm{~cm}$ ).

When lumping cut height yielding zero and one branch whorl, the ANOVA analysis indicates that a significant difference exists in the mean (lumped) between sites (Prob. $>\mathrm{F}<0.0001$ ). The thinning height observed in site 1 is significantly inferior to the other sites, while the thinning height in site 3 is significantly inferior to sites 2 and 4 (Tukey 


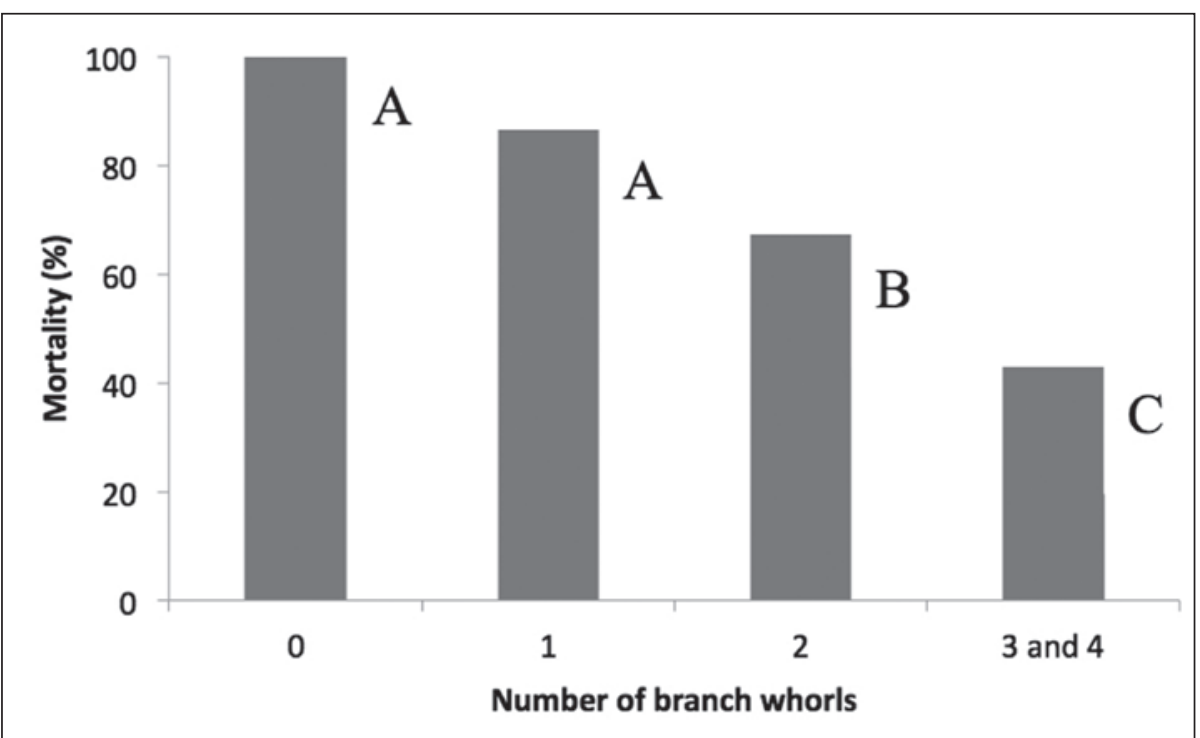

Fig. 5. Percent stem mortality as a function of number of branch whorls for all sites lumped (Prob. $>\mathrm{Chi}^{2}<0.0001$ ).
Mortality proportion versus the number of remaining branch whorls

The objective of thinning is to reduce competition and stem density; thus, treatments that result in $100 \%$ thinned stem mortality are considered highly successful. Jack pine is not capable of sprouting new shoots from the root collar or roots following precommercial thinning, and must rely on remaining living branches. We observed that if precommercial thinning removed all branches, $100 \%$ stem mortality occurred.

$\mathrm{Chi}^{2}$ for all sites lumped indicated significant differences in mortality frequency based on remaining number of branch whorls. Therefore, the more branch whorls left on the stem, the higher the survival rate.
HSD). Variables were log-transformed as ANOVA assumptions of normality and homoscedasticity were not met. Site 1 has a mean of $9 \mathrm{~cm}(95 \% \mathrm{CI}$ of $8 \mathrm{~cm}$ and $10 \mathrm{~cm})$, site 3 a mean thinning height of $12 \mathrm{~cm}(95 \%$ CI of $12 \mathrm{~cm}$ and $13 \mathrm{~cm})$ and sites 2 and 4 a mean thinning height of $17 \mathrm{~cm}(95 \%$ CI of $17 \mathrm{~cm}$ and $18 \mathrm{~cm})$.

\section{Discussion \\ Mean cut height by site}

The statistical analysis indicates that thinning operations were carried out at significantly different heights depending on the site. In Quebec, thinning height is regulated at a maximum of $20 \mathrm{~cm}$ with tolerance based on terrain obstacles (MRNF 2011). This analysis indicates that thinning was not implemented at the proper cut height in two out of the four sites sampled, and even when it was, re-growth of thinned stems was still observed. The high cut height observed in site 2 was due to the presence of dense ericaceous cover, which obstructed the regulated thinning height zone; however, no such obstructions existed in site 4 , indicating poor treatment application. Therefore, a revision of existing practices is suggested.

\section{Number of branch whorls versus cut height}

Results show that the higher precommercial thinning is applied on a stem, the more branch whorls will remain. Although this is inherently obvious, it is still necessary to illustrate in the context of our argument. The analysis of covariance indicates significant differences in the Y-intercept but not the slopes among sites. The differences in the number of branch whorls observed at any given cut height can be explained by differing growth rates between sites. This is most likely due to on-site characteristics such as nutrient availability, quality of drainage, soil temperature, $\mathrm{pH}$ and moisture regime, light availability, or competition with other species. These characteristics are known to influence jack pine stem growth and stand productivity (Bonan and Shugart 1989, Rudolph and Laidly 1990, Bell 1991).

\section{Thinning height leaving 0 branch whorls on thinned stems by site}

The only way to achieve $100 \%$ stem mortality following precommercial thinning of jack pine stems is to effectively remove all branch whorls with treatment application, but what cut height would achieve this objective? Results from ANOVA and Tukey HSD examining the mean cut height that yields zero branch whorls indicate that site 1 , with a mean thinning height of $5 \mathrm{~cm}$, is significantly different from the other three sites. This is most likely due to the excessive drainage and the shallow thickness of the organic matter $(2 \mathrm{~cm})$ (Table 1$)$, which by extension would decrease nutrient availability and increase drought susceptibility, resulting in poorer stem growth. Low initial growth rates would result in a relatively higher proportion of branch whorls closer to the ground at the time of thinning (Fig. 4), thereby increasing survival. Stands that exhibit these characteristics should not be thinned until self-pruning has killed the branch whorls closest to the ground.

All other sites are similar, with a mean thinning height of 11 $\mathrm{cm}$, which is not surprising given that jack pine displays optimal growth in moderate mesic to light xeric conditions (Rudolph and Laidly 1990, Beland and Bergeron 1996). The results indicate that among sites that did not show a statistical significance in terms of cutting height leaving zero whorls on the stem, a cutting height of $11 \mathrm{~cm}$ is sufficient. These results correspond very well with the minimum cutting height outlined by Forrester and von der Gonna (1990), who considered $10 \mathrm{~cm}$ to be the shortest stem thinning height without any loss in worker productivity. Treatment costs will increase in stands where thinning is carried out as close to the ground as possible (as would have to be done in site 1) due to the additional input of time required (Forrester 1989, Forrester and von der Gonna 1990).

In young stands where it may not be possible to thin close to the ground due to obstructions such as rocks, stumps, wood, a dense cover of ericaceous species, or high topographic variability, stand density could be a useful indicator of the timing of the onset of self-pruning in jack pine. This would allow foresters to better predict when the lowest branches experience 
the greatest mortality in order to better time precommercially thinning operations. As previously mentioned, self-pruning of lower branches in jack pine stands typically occurs between 6 and 12 years; however, it is density-dependent (Vassov and Baker 1988). The greater the stem density the faster self-pruning will begin. Thus, in very dense sites thinning operations could be scheduled earlier than less dense sites, because of higher mortality of lower branches.

Excessively drained sites that lack a thick organic layer and surface vegetation tend to have limited nutrient resources and are more susceptible to drought. In these sites the growth of jack pine can be greatly reduced, thus potentially delaying the onset of self-pruning. Even though they may contain high stem densities (as observed in site 1) re-growth of thinned stems can remain high. In addition, jack pine is a highly shade-intolerant species (Fowells 1965, Rudolph and Laidly 1990, Sims et al. 1990, Claveau et al. 2002). Although this study did not examine the direct effects of thinning on stand solar insolation levels, it appears that stands thinned earlier, or stands that exhibit poor growth (as mentioned above), have relatively more light than those thinned later due to the presence of relatively shorter unthinned trees (Splawinski 2010, personal observation). Higher levels of insolation may decrease the mortality of the remaining branches on thinned stumps by providing enough energy through photosynthesis to survive; indeed in site 1 the survival of thinned stumps tended to be greater around relatively shorter residual trees.

Recent research has indicated that jack pine is capable of root grafting (Tarroux et al. 2010; Tarroux and DesRochers 2010, 2011), which allows for the sharing of resources among connected trees (Tarroux and DesRochers 2011). Grafting is minimal in the first 10 years; however, it increases to $\sim 10 \%$ by a stand age of 11 to 20 years (Tarroux and DesRochers 2010). Surviving stumps constitute a resource drain on un-thinned grafted individuals, which results in decreased growth rates (Tarroux et al. 2010). Thinning at an earlier age would reduce or eliminate this issue.

\section{Recommendations}

We suggest that precommercial thinning in dense jack pine stands be applied between 7 and 10 years following establishment, similar to the recommendation made by Smith (1984) and Vassov and Baker (1988), to minimize treatment costs and maximize growth. In addition we recommend that precommercial thinning operations be carried out between $10 \mathrm{~cm}$ and 13 $\mathrm{cm}$, given that 1) $\mathrm{Chi}^{2}$ analysis revealed no significant difference in mortality frequency between zero and one remaining branch whorl (Fig. 5); and 2) a significant difference exists between site 3 and sites 2 and 4 when data are lumped for zero and one remaining branch whorl (employing the precautionary principle, we provide the upper $95 \%$ CI for site 3 ). However, if foresters wish to ensure maximum mortality of thinned stems, we suggest a thinning height of $10 \mathrm{~cm}$. Workers should be instructed to follow this guideline, with emphasis placed on the importance of this factor on thinning success. In a study by Smith (1984) workers were instructed to thin as close to the ground as possible, resulting in re-growth of $<1 \%$.

The suggestions outlined here are meant as general guidelines to precommercial thinning. Final decisions should be based, if possible, on on-site observations made by foresters responsible for planning operations. Onset of the self-pruning phase (and by extension proportion of lower branch mortality), stand density, obstructions on the forest floor (rocks, wood, ericaceous species), and mean bole height until first living branch whorl, are all useful indicators. For example, 1) if branch whorls on individual species are dead at $>10 \mathrm{~cm}$ then it would be possible to apply thinning regardless of stand age. 2) If there is a heavy presence of ericaceous species, and/or rocks, wood that exceeds the $10 \mathrm{~cm}$ thinning prescription then it may be useful to delay treatment until self-pruning kills the branch whorls in the obstructed area.

\section{Conclusion}

Results of this study indicate that thinning height has a significant effect on the remaining number of branch whorls, which in turn affects the survival rate of thinned stems; the lower the cut height the higher the mortality. We suggest that precommercial thinning operations be delayed in excessively drained stands and those with obstacles present (rocks, wood, ericaceous species) until self-pruning kills the branch whorls in the obstructed zone. In stands that do not exhibit this problem, a cut height of $10 \mathrm{~cm}$ to $13 \mathrm{~cm}$ should be employed to maximize the mortality of thinned stems. These stands should be thinned between 7 and 10 years after disturbance.

\section{Acknowledgements}

We thank Resolute Forest Products and Tembec for providing fire and silvicultural treatment information, Mélanie Desrochers for GIS and mapping support, and Stéphane Daigle for statistics support. Funding was provided by the following: NSERC RDC, Volet 1, FQRNT BMP scholarship, and Resolute Forest Products. Laurent Torres, Andreyi Poklonnyi, and Rik Van Bogaert assisted in the field.

\section{References}

Beland, M., and Y. Bergeron. 1996. Height growth of jack pine (Pinus banksiana) in relation to site types in boreal forests of Abitibi, Quebec. Can. J. For. Res. 26: 2170-2179.

Bell, W.F. 1991. Critical silvics of conifer crop species and selected competitive vegetation in Northwestern Ontario. For. Can., Ont. Region, Sault Ste. Marie, Ont. / Northw. Ont. For. Tech. Dev. Unit, Min. Nat. Resour., Thunder Bay, Ont. COFRDA Rep. 3310 / NWOFTDU Tech. Rep. 19.177 p.

Bella, I.E. 1974. Growth response of young jack pine to mechanical strip thinning. Manitoba. Dep. Environ., Can. For. Serv., Edmonton, AB. Inf. Rep. NOR-X102. 11 p.

Bella, I.E. and J.P. de Franceschi. 1974. Commercial thinning improves growth of jack pine. Dep. Environ., Can. For. Serv., Edmonton, AB. Inf. Rep. NOR-X112. 23 p.

Benzie, J.W. 1983. Thinning study in a dense young jack pine stand. USDA For. Serv., For. Sci. Lab., Grand Rapids, MN. 2 p.

Bonan, G.B. and H.H. Shugart. 1989. Environmental factors and ecological processes in boreal forests. Annu. Rev. Ecol. Syst. 20: 1-28.

Buckman, R.E. 1964. Twenty-two year results of a precommercial thinning experiment in jack pine. USDA For. Serv., Lake States For. Exp. Stn., Res. Note LS-46. 2 p.

Bulley, B., C. Bowling and G. Niznowski. 1997. Jack pine leader clipping trial: fifth year results. Ont. Min. Nat. Resour., NWST, Thunder Bay, ON. TR-106. 2 p.

Cayford, J.H. 1961. Results of a 1927 jack pine thinning in Saskatchewan. Dep. For., For. Res. Br., Ottawa. Tech. Note 107. 13 p.

Cayford, J.H. 1964. Results of a 1921 jack pine thinning in western Manitoba. Dep. For., Ottawa. Publ. 1077. 8 p. 
Claveau, Y., C. Messier, P.G. Comeau and K.D. Coates. 2002. Growth and crown morphological responses of boreal conifer seedlings and saplings with contrasting shade tolerance to a gradient of light and height. Can. J. For. Res. 32: 458-468.

De Groot, W.J., P.M. Bothwell, S.W. Taylor, B.M. Wotton, B.J. Stocks and M.E. Alexander. 2004. Jack pine regeneration and crown fires. Can. J. For. Res. 34: 1634-1641.

Enright, N.J., R. Marsula, B.B. Lamont and C. Wissel. 1998. The ecological significance of canopy seed storage in fire-prone environments: a model for resprouting shrubs. J. Ecol. 86: 960-73.

Forrester, P.D. 1989. The effects of live-limb removal on clearing-saw productivity. Forest Engineering Research Institute of Canada, Vancouver, BC. FERIC Technical Note No. TN-129. 7 p.

Forrester, P.D. and M.A. von der Gonna. 1990. Development of live limbs on stumps following juvenile spacing. Forest Engineering Research Institute of Canada, Vancouver, BC. FERIC Special Report No. SR-69. 15 p.

Fowells, H.A. 1965. Silvics of the forest trees of the United States. U.S. Dep. Agric. Agric. Handb. 271.

Gauthier, S., Y. Bergeron and J.-P. Simon. 1993. Cone serotiny in jack pine: ontogenetic, positional, and environmental effects. Can. J. For. Res. 23: 394-401.

Gay, R.C. 1987. Live branch survival and growth response in juvenilespaced lodgepole pine in the Nor fire (BCMOF SX Trial No. 82408); unpublished report submitted to the Assoc. of B.C. Professional Foresters.

Goble, B.C. and C. Bowling. 1993. Five-year growth response of thinned jack pine near Atikokan, Ontario. Ont. Min. Natur. Resour., Northwest Reg. Sci. and Technol., Thunder Bay, ON. Tech. Note TN23. $13 \mathrm{p}$.

Greene, D.F., J.C. Zasada, L. Sirois, D. Kneeshaw, H. Morin, I. Charron and M.-J. Simard. 1999. A review of the regeneration dynamics of North American boreal forest tree species. Can. J. For. Res. 29: 824-839. Lamont, B.B., D.C.L. Maitre, R.M. Cowling and N.J. Enright. 1991. Canopy seed storage in woody plants. Bot. Rev. 57: 277-317.

Morris, D.M., C. Bowling and S.C. Hills. 1994. Growth and form responses to precommercial thinning regimes in aerially seeded jack pine stands: 5th year results. For. Chron. 70(6): 780-787.

[MRNF] Ministère des Ressources naturelles et de la Faune. 2011. Instructions relatives à l'application de l'arrêté ministériel sur la valeur des traitements sylvicoles admissibles en paiement des droits - Exercices 2010-2013. Direction de l'aménagement et de lenvironnement forestiers. $129 \mathrm{p}$.

Riley, L.F. 1973. Operational trials of techniques to improve jack pine spacing. Dep. Environ., Can. For. Serv., Sault Ste. Marie, ON. Inf. Rep. $0-\mathrm{X}-180.26 \mathrm{p}$.
Rudolph, T.D. and P.R. Laidly. 1990. Pinus banksiana Lamb. Jack pine. In R.M. Burns and B.H. Honkala (tech. coords.). Silvics of North America: 1 Conifers. Vol. 1. Agricultural Handbook 654. U.S. Department of Agriculture, Forest Service, Washington, DC. 675 p.

[OMNR] Ontario Ministry of Natural Resources. 1998. Early stand tending in jack pine plantations. A demonstration forest program publication. Technical report \#6. Science and Information Resources Division. Northwest Science and Technology, Thunder Bay, ON. 24 p.

Sims, R.A., H.M. Kershaw and G.M. Wickware. 1990. The autoecology of major forest species in the north central region of Ontario. Forestry Canada, Ontario Region, Sault Ste. Marie, ON. Can.-Ont. For. Resour. Dev. Agree. Rep. 3302.

Skilling, D.D. 1957. Twelve-year results of a mechanical thinning in over-dense jack pine. USDA For. Serv., Lake States For. Exp. Stn., Tech. Note No. 489. 1 p.

Smith, C.R. 1984. Precommercial thinning in jack pine with particular reference to experiments in Northeastern Ontario. In C.R. Smith and G. Brown (eds.). Jack Pine Symposium. pp. 122-130. Can. For. Serv., Great Lakes For. Res. Cent., Sault Ste. Marie, ON. and Ont. Min. Natur. Resour., Toronto, ON. COJFRC Symposium Proc. O-P-12. 195 p.

Splawinski, T.B., S. Gauthier, Y. Bergeron and D.F. Greene. Unpublished. Juvenile stage regeneration dynamics of Pinus banksiana and Picea mariana following fire, salvage, and silvicultural treatment.

Steneker, G.A. 1969. Strip and spaced thinning in overstocked jack pine and black spruce stands. Dep. Fish. For., For. Br., For. Res. Lab., Winnipeg, Man. Inf. Rep. MS-X-16. 14 p.

Tarroux, E. and A. DesRochers. 2010. Frequency of root grafting in naturally and artificially regenerating stands of Pinus banksiana: influence of site characteristics. Can. J. For. Res. 40: 861-871.

Tarroux, E. and A. DesRochers. 2011. Effect of natural root grafting on growth response of jack pine (Pinus banksiana; Pinaceae). American Journal of Botany. 98: 967-974.

Tarroux, E., A. DesRochers and C. Krause. 2010. Effect of natural root grafting on growth response of jack pine (Pinus banksiana) after commercial thinning. Forest Ecology and Management. 260: 526-535.

Van Damme, L. and K. McKee. 1990. The extent and nature of seeded jack pine clumping following disturbance in Northwestern Ontario. Ont. Min. Natur. Resour., Northwestern Ont. For. Tech. Dev. Unit, Thunder Bay, ON. Tech. Rep. No. 58. 42 p.

Vassov, R. and W.D. Baker. 1988. Precommercial thinning of jack pine. Ont. Min. Nat. Res., NW Ont. For. Tech. Dev. Unit, Thunder Bay, Ontario. Tech. Rep. No. 12.25 p. 